Available online on 15.1.2019 at http://ujpr.org
Universal Journal of Pharmaceutical Research
An International Peer Reviewed Journal
Open access to Pharmaceutical research

\title{
PREVALENCE OF HEPATITIS G VIRUS AMONG PATIENTS WITH CHRONIC LIVER DISEASE AND HEALTHY INDIVIDUALS, SANA'A CITY-YEMEN

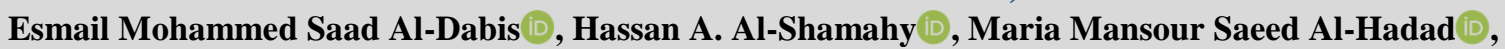 Emad Hassan Al-Shamahi
}

Medical Microbiology and Clin. Immunology, Faculty of Medicine and Health Sciences, Sana'a University, Republic of Yemen.

\section{ABSTRACT}

Objective: Hepatitis G virus (HGV) is a newly discovered and enveloped RNA positive-stranded flavivirus-like particle, which has not yet been proven to have major negative effects on liver. Therefore, it is important to estimate the prevalence and risk factors of hepatitis $\mathrm{G}$ virus infection in Yemeni viral hepatitis patients and general population to design standard prevention and treatment plans.

Methods: Screening HGV antibodies among 60 chronic HBV and 144 chronic HCV patients comparing with its prevalence in 218 healthy controls were carried out. Serum samples were collected and tested for human HGV IgG by commercially available ELISA technique. Demographic data such as gender, age, and risk factors of contracting HGV virus were recorded in predesigned questionnaire.

Results: The crude prevalence rate of $\mathrm{HGV}$ was $2.8 \%$, female specific rate was $0 \%$ and male specific rate was $3.5 \%$. The prevalence of $\mathrm{HGV}$ among $\mathrm{HBV}$ patients was $0 \%$; $\mathrm{HCV}$ was $1.4 \%$ while in healthy individuals it was $4.6 \%$. When age groups considered, the prevalence of HGV among age groups 20-29 years and 30-39 years was 3.5\%, while in older age groups the rate of HGV was $0 \%$. There was a trend towards increased levels of HGV infection with the second and third decades of life (3.5\%). There was no significant association between HGV infection and risk factors of hepatitis viruses.

Conclusion: It can be concluded from this study that HGV virus is circulating in the risk groups and in the community in general Yemen, and there is a possibility that this virus may at some time become epidemic if preventive measures are not applied. The risk of community among healthy people more than in risk groups as HBV and HCV patients. Additionally HGV increases with young male adults.

Keywords: Hepatitis G virus (HGV), HBV, HCV, Prevalence, Sana'a city-Yemen.

Article Info: Received 3 November 2018; Revised 4 December; Accepted 27 December, Available online 15 January 2019

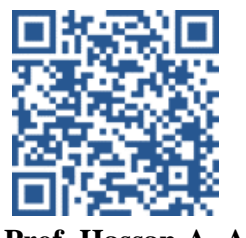
Cite this article-

Al-Dabis EMS, Al-Shamahy HA, Al-Hadad MMS, Al-Shamahi EH. Prevalence of hepatitis G virus among patients with chronic liver disease and healthy individuals, Sana'a city-Yemen. Universal Journal of Pharmaceutical Research 2018; 3(6): 1-5.

DOI: https://doi.org/10.22270/ujpr.v3i6.216

Address for Correspondence:

Prof. Hassan A. Al-Shamahy, Faculty of Medicine and Heath Sciences, Sana'a University, P.O. Box 775 Sana'a, Yemen. Phone: +967-770299847, E-mail: shmahe@yemen.net.ye

\section{INTRODUCTION}

From 1995 to 1996, two independent laboratories in the USA isolated a new enveloped RNA virus similar to flavi viruses. The first laboratory named it GB virus $\mathrm{C} / \mathrm{GBV}-\mathrm{C}$ and the second as hepatitis $\mathrm{G}$ virus $(\mathrm{HGV})^{1}$. $\mathrm{HGV}$ is a virus in the flaviviridae family and known to be infectious for human, but it has not been established to cause human disease with certainly ${ }^{2}$. However, there is a suspicious link between HGV infection and acute or fulminant hepatitis, chronic hepatitis and hepatic fibrosis ${ }^{3,4}$. High prevalence is observed among subjects with risk of parenteral exposure including those with exposure to blood and blood products ${ }^{5}$. Approximately, $2 \%$ of healthy United States blood donors had viremia with $\mathrm{HGV}$ and up to $13 \%$ of blood donors had antibodies against E2 protein, indicating a possible prior infection ${ }^{6}$. Sexual contact and vertical transmission could be another route of $\mathrm{HGV}$ transmission ${ }^{6}$. Furthermore, HCV and HBV infected patients have evidence of higher rate of $\mathrm{HGV}$ infection $^{7,8}$. However, none of the studies indicated that HGV infection can cause any liver enzyme elevation or hepatic failure certainly, but co-infection with other hepatitis viremia can increase morbidity and mortality rates'. HGV prevalence rate among healthy and the role of this agent in acute and chronic liver disease in Yemen is absent or at least poorly understood, so this study was carried out as one of the first study to detected the prevalence rate of $\mathrm{HGV} / \mathrm{GBV}-\mathrm{C}$ among $\mathrm{HBV}$ and $\mathrm{HCV}$ infected patients comparing with healthy controls, and risk factors of transmission 
$\mathrm{HGV} / \mathrm{GBV}-\mathrm{C}$ and the co-infection with HBV and HCV in Yemen.

\section{SUBJECTS AND METHODS}

This study was carried out during a period of nine months, starting in March 2015 and ending in November 2015. A total of 422individuals were included; 218 healthy controls, 60 of chronic HBV patients and 144 chronic $\mathrm{HCV}$ patients attended to the main general hospitals in the Sana'a city. Serum samples were collected and tested for human HGV IgG by commercially available ELISA technique (Roche). A full history was taken from each studied individual; and the findings were recorded in a predesigned questionnaire. The data collected included name, age at the time of the study, sex, marital status, residence, date, clinical and diagnostic data, risk factors and laboratory results.

Table 1: The prevalence rate and association odds ratio of HGV among HBV, HCV patients and healthy controls.

\begin{tabular}{|c|c|c|c|c|c|c|}
\hline \multirow[t]{2}{*}{ Characters } & \multicolumn{2}{|c|}{$\begin{array}{l}\text { Anti-E2 positive } \\
\text { (HGV positive) }\end{array}$} & \multirow[t]{2}{*}{ OR } & \multirow[t]{2}{*}{ CI } & \multirow[t]{2}{*}{$\chi^{2}$} & \multirow[t]{2}{*}{$\mathbf{P}$} \\
\hline & No & $\%$ & & & & \\
\hline HBV chronic patients $n=60$ & 0 & 0 & 0 & $0.0-2.6$ & 2.1 & 0.15 \\
\hline HCV chronic patients $n=144$ & 2 & 1.4 & 0.36 & $0.05-1.8$ & 1.8 & 0.17 \\
\hline Healthy controls $n=218$ & 10 & 4.6 & 4.8 & $1.04-32.5$ & 5 & 0.02 \\
\hline Total $n=422$ & 12 & 2.8 & & & & \\
\hline
\end{tabular}

OR Odds ratio $=\mathrm{RR}$ (relative risk) $\Rightarrow$ 1 at risk, CI-Confidence intervals, $\chi^{2}$ Chi-square $=\geq 3.84$ (significant), $p$-Probability value $=<0.05$ (significant)

Table 2: The prevalence rate and associated odds ratio of HGV among different sexes and age groups among total patients and controls.

\begin{tabular}{|c|c|c|c|c|c|c|}
\hline \multirow[t]{2}{*}{$\begin{array}{l}\text { Sex and age } \\
\text { groups }\end{array}$} & \multicolumn{2}{|c|}{$\begin{array}{l}\text { Anti-E2 positive } \\
\text { (HGV positive) }\end{array}$} & \multirow[t]{2}{*}{ OR } & \multirow[t]{2}{*}{ CI } & \multirow[t]{2}{*}{$\chi^{2}$} & \multirow[t]{2}{*}{$\mathbf{P}$} \\
\hline & No & $\%$ & & & & \\
\hline \multicolumn{7}{|l|}{ Sex } \\
\hline Male $n=342$ & 12 & 3.5 & \multicolumn{2}{|c|}{ undefined } & 422 & $<0.001$ \\
\hline Female $n=80$ & 0 & 0 & 0.0 & $0.0-1.8$ & 2.9 & 0.08 \\
\hline \multicolumn{7}{|l|}{ Age groups } \\
\hline $20-29$ years & & 3.5 & 1.44 & $0.4-5.14$ & 0.39 & 0.53 \\
\hline $\mathrm{N}=170$ & 6 & & & & & \\
\hline $\begin{array}{l}30-39 \text { years } \\
N=114\end{array}$ & 4 & 3.5 & 1.4 & $0.34-5.12$ & 0.25 & 0.61 \\
\hline $\begin{array}{l}40-49 \text { years } \\
N=60\end{array}$ & 0 & 0 & 0.0 & $0.0-2.6$ & 2.1 & 0.15 \\
\hline $\begin{array}{l}50-59 \text { years } \\
N=50\end{array}$ & 0 & 0 & 0.0 & $0.0-3.2$ & 1.7 & 0.19 \\
\hline$>59$ years $n=28$ & 2 & 7.1 & 2.95 & $0.0-15.5$ & 2.01 & 0.15 \\
\hline
\end{tabular}

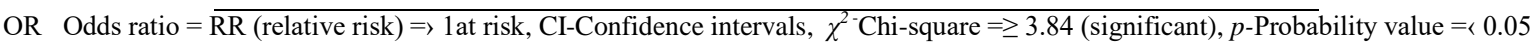
(significant)

\section{Statistical Analysis}

To relate possible risk factors for HGV infection, the data were examined in a case-control study format. For $\mathrm{HGV}$, persons with evidence of previous or current infection with HGV (antibodies-positive) were matched up with those who were $\mathrm{HGV}$ antibodies negative.

\section{Ethical Consideration}

Ethical clearance for the study was taken from the Faculty of Medicine and Health Sciences Research Review Committee. Informed Consent was taken from the volunteers before the collecting specimens.

\section{RESULTS}

The crude prevalence rate of $\mathrm{HGV}$ was $2.8 \%$, female specific rate was $0 \%$ and male specific rate was $3.5 \%$. The prevalence of HGV among HBV patients was $0 \%$; $\mathrm{HCV}$ was $1.4 \%$ while in healthy individuals it was $4.6 \%$. When age groups considered, the prevalence of HGV among age groups 20-29 years and 30-39 years was $3.5 \%$, while in older age groups the rate of $\mathrm{HGV}$ was $0 \%$.

Risk Factors to HGV: From the study participants $8.7 \%$ reported that they had direct contact with hepatitis patients, $3.1 \%$ had sexual contact with HBV or HCV patients, $8.3 \%$ had household with HBV or HCV patients, $47.4 \%$ had history of dental visit, 68.2 sharing blades and scissors, $10.2 \%$ had blood transfusion, $16.6 \%$ had cupping and $33 \%$ had history of surgery (Table 3).

Associated Odds ratio of HGV: There were significant risk factors of $\mathrm{HGV}$ with males in which the rate was $3.5 \%$, while in female the rate was $0 \%$ $(\mathrm{p}<0.001)$. In respect of age groups, there were no significant risk factors of $\mathrm{HGV}$ (Table 2). In respect of risk factors, there were no significant risk factors of $\mathrm{HGV}$ with usual risk factors of hepatitis $\mathrm{G}$ virus (Table 4). 


\section{DISCUSSION}

The present study represents the first investigation of HGV infection in patients with chronic hepatitis B and HCV living in Sana'a city, Yemen. HGV was detected by ELISA in $12(2.8 \%)$ of all patients and healthy controls. The rate of $\mathrm{HGV}$ was $0 \%$ for HBV-infected patients, $1.4 \%$ for $\mathrm{HCV}$-infected patients and $4.6 \%$ for healthy controls. The values related to co-infection of HGV with HCV and HBV in current study were lower from that reported by Amini et al., Ghanbari et al., and Zali et al., in Iran in which the rate of HGV with HBV was varying between $5 \%$ and $43 \%^{10,11,12}$. Also, Yang et al., in Taiwan showed that co-infections of HGV with HBV and HCV were $18 \%$ and $55 \%$, respectively ${ }^{13}$, Tanaka et al., 1998 in Japan showed that co-infection of $\mathrm{HGV}$ with $\mathrm{HCV}$ was $10.9 \%{ }^{14}$, in Thailand Barusruk and Urwijitaroon et al., 2006 showed that co-infection with HCV was $10 \%{ }^{15}$, and in
Egypt HGV with HCV was $64.9 \%^{16}$. Additionally, in some studies, co-infection of $\mathrm{HGV}$ with $\mathrm{HCV}$ and HBV was reported with lower values than that of Iran and Taiwan. Alvarado-Mora et al., in Colombia reported that $5.06 \%$ of $\mathrm{HBs} \mathrm{Ag}$-positive samples were also HGV-positive, while $3.2 \%$ of $\mathrm{HCV}$ positive cases were $\mathrm{HGV}$-positive ${ }^{17}$, which in the case of $\mathrm{HBV}$ samples is higher to current findings but much slightly higher than the co-infection rate of $\mathrm{HGV}$ and $\mathrm{HCV}$ in the present study $(1.4 \%)$. There is a large variation and difference in the prevalence of $\mathrm{HGV}$ infection in different geographical regions. This difference may be due to the volume of the population involved in the study, methodology used to detect HGV infection, demographic and clinical features of patients, and different patterns of transmission of virus around the world (blood and blood components, sexual routes, intravenous injection, etc ${ }^{18}$.

Table 3: The risk factors to HGV in tested hepatitis patients and healthy controls at Sana'a city.

\begin{tabular}{lllll}
\hline \multirow{2}{*}{ Risk factors } & \multicolumn{2}{c}{ Yes } & \multicolumn{2}{c}{ No } \\
\cline { 2 - 5 } & No & \% & No & \% \\
\hline $\begin{array}{l}\text { Direct contact with hepatitis } \\
\text { patients }\end{array}$ & 37 & 8.7 & 385 & 63 \\
\hline Sexual contact: with HBV, HCV & 13 & 3.1 & 409 & 87 \\
\hline Household with HBV, HCV & 35 & 8.3 & 387 & 91.7 \\
\hline Abroad travel & 42 & 10 & 380 & 90 \\
\hline History dental visit & 200 & 47.4 & 222 & 52.6 \\
\hline History sharing blades, scissors & 288 & 68.2 & 134 & 31.8 \\
\hline Blood transfusion & 43 & 10.2 & 279 & 89.8 \\
\hline History parental exposure & 3 & 0.71 & 419 & 99.29 \\
\hline History of cupping & 70 & 16.6 & 352 & 83.4 \\
\hline History of surgery & 97 & 33 & 325 & 77 \\
\hline
\end{tabular}

Table 4: The potential risk factors of HGV infection in total patients and controls groups.

\begin{tabular}{|c|c|c|c|c|c|c|}
\hline \multirow[t]{2}{*}{ Risk factors } & \multicolumn{2}{|c|}{$\begin{array}{l}\text { Anti-E2 positive } \\
\text { (HGV positive) }\end{array}$} & \multirow[t]{2}{*}{ OR } & \multirow[t]{2}{*}{ CI } & \multirow[t]{2}{*}{$\chi^{2}$} & \multirow[t]{2}{*}{$\mathbf{P}$} \\
\hline & No & $\%$ & & & & \\
\hline Direct contact with hepatitis patients $n=37$ & 0 & 0 & 0.0 & $0.0-4.5$ & 1.19 & 0.27 \\
\hline $\begin{array}{l}\text { Sexual contact: with } \\
\text { HBV, HCV }(\mathrm{n}=13)\end{array}$ & 0 & 0 & 0.0 & $0.0-14.7$ & 0.39 & 0.53 \\
\hline $\begin{array}{l}\text { Household with } \\
\text { HBV, HCV }(\mathrm{n}=35)\end{array}$ & 0 & 0 & 0.0 & $0.0-4.8$ & 1.12 & 0.29 \\
\hline Abroad travel: $(n=42)$ & 0 & 0 & 0.0 & $0.0-3.93$ & 1.37 & 0.24 \\
\hline $\begin{array}{l}\text { History dental visit: } \\
(\mathrm{n}=200)\end{array}$ & 4 & 2 & 0.55 & $0.14-2$ & 0.98 & 0.32 \\
\hline History repeated use of needles: $(\mathrm{n}=0)$ & 0 & 0 & \multicolumn{4}{|c|}{ undefined } \\
\hline History sharing blades, scissors $(\mathrm{n}=288)$ & 6 & 2.1 & 0.4 & $0.12-1.5$ & 2.3 & 0.12 \\
\hline $\begin{array}{l}\text { Blood hemodialysis } \\
(\mathrm{n}=0)\end{array}$ & 0 & 0 & \multicolumn{4}{|c|}{ undefined } \\
\hline $\begin{array}{l}\text { Blood transfusion } \\
(\mathrm{n}=43)\end{array}$ & 1 & 2.3 & 0.77 & $0.1-5.9$ & 0.06 & 0.8 \\
\hline History parental exposure $(\mathrm{n}=3)$ & 0 & 0 & 0.0 & $0.0-86$ & 0.09 & 0.76 \\
\hline History patient receive a tattoo: $(\mathrm{n}=0)$ & 0 & 0 & \multicolumn{4}{|c|}{ undefined } \\
\hline $\begin{array}{l}\text { History of cupping: } \\
(\mathrm{n}=70)\end{array}$ & 2 & 2.9 & 0.98 & $0.2-4.3$ & 0.00 & 0.97 \\
\hline $\begin{array}{l}\text { History of surgery: } \\
(\mathrm{n}=97)\end{array}$ & 2 & 2.1 & 0.6 & $0.1-3.19$ & 0.32 & 0.56 \\
\hline
\end{tabular}

OR Odds ratio $=$ RR (relative risk) $\Rightarrow 1$ at risk, CI-Confidence intervals, $\chi^{2}$ Chi-square $=\geq 3.84$ (significant), $p$-Probability value $=<0.05$ (significant)

However, the present study represents the first investigation of $\mathrm{HGV}$ infection in healthy controls in Yemen. The HGV prevalence rate in the present study among healthy controls was $4.6 \%$, higher than that in hepatitis patients $(0 \%$ with $\mathrm{HBV}$, and $1.4 \%$ with $\mathrm{HCV})$.
The rate among healthy individuals is lower than that reported from $\mathrm{Africa}^{19}(33 \%), \mathrm{US}^{20}(13 \%)$, and the $33 \%$ of China $^{21}$. Thus HGV infection prevalence in Yemeni healthy people $(4.8 \%)$ could be regarded as a low level. Since in the present study 218 healthy 
individuals were enrolled and selected randomly, the calculated prevalence data for hepatitis $G$ in them are reliable. However, in general, all results published showed that hepatitis $G$ infection was uncommon in healthy individuals, and this was also confirmed by current study. The specific female prevalence of HGV was $0 \%$ among both patients and healthy control females, while male prevalence was $3.5 \%$. Current study result was different to the sex distribution of HGV /GBV-C infection in western countries where equal distribution is the feature in all reports ${ }^{22,23}$. In addition; the present study showed that there was trend toward increased levels of HGV/GBV-C infection with the second, and the third decades of life where the rates were $3.5 \%$, with $\mathrm{OR}=1.4$, and $7.1 \%$ with $\mathrm{OR}=2.95$ respectively. This similar to findings in prospective study of 2796 hemodialysis patients seen in Germany ${ }^{24}$ which reported that higher prevalence of $\mathrm{HGV} / \mathrm{GBV}-\mathrm{C}$ were in the $3^{\text {rd }}$ decades of life among hemodialysis patients. The increasing of prevalence rate with increasing age in current study could indicate an accumulation risk of infection over time. There was no significant association between $\mathrm{HGV} / \mathrm{GBV}-\mathrm{C}$ infection and history of all parenteral transmission routes (Table 4), and this opposite to the findings by Fogeda et al., ${ }^{25}$ and Basaras et al., ${ }^{26}$ that prior factors were risk factors for $\mathrm{HGV} / \mathrm{GBV}-\mathrm{C}$ in Spain and Germany.

\section{CONCLUSION}

It can be concluded from this study that HGV virus is circulating in the risk groups and in the community in Sana'a city, and there is a possibility that this virus may at some time become epidemic if preventive measures are not applied. The risk of exposure to HGV increases with advancing age, and no significant risks of contracting HGV through parenteral transmission.

\section{ACKNOWLEDGEMENTS}

The authors would like to acknowledge Sana'a University, and the Microbiology Department of the National Centre of Public Health Laboratories (NCPHL) Sana'a, Yemen which provided working space.

\section{AUTHOR'S CONTRIBUTION}

This research work is part of A MSc. thesis. The candidate is the first authorr (EMSD) who conducted the laboratory and field works; and wrote up the thesis. The corresponding author (HAA) supervised the laboratory and field works, revised and edited the thesis draft and the manuscript and EHA and MMA helped in conducted the field works.

\section{CONFLICT OF INTEREST}

No conflict of interest associated with this work.

\section{REFERENCES}

1. Zuckerman AJ. Alphabet of hepatitis viruses. Lancet 1996; 347(9001):558-9. https://doi.org/10.1016/s0140-6736(96)91267-2

2. Mosam A, Sathar MA, Dawood H, Cassol E, Esterhuizen TM, Coovadia HM. Effect of GB virus C co-infection on response to generic HAART in African patients with HIV-1 clade C infection. AIDS 2007; 21(10):1377-9. https://doi.org/10.1097/QAD.0b013e3281532cb8

3. Ling BH, Zhuang H, Cui YH, An WF, Li ZJ, Wang SP, et al. A cross-sectional study on $\mathrm{HGV}$ infection in a rural population. World J Gastroenterol 1998; 4(6):489-92. https://doi.org/10.3748/wjg.v4.i6.489

4. Cornu C, Jadoul M, Loute G, Goubau P. Hepatitis G virus infection in haemodialysed patients: epidemiology and clinical relevance. Nephrol Dial Transplant 1997; 12 (7):1326-9. https://doi.org/10.1093/ndt/12.7.1326

5. Halasz R, Weiland O, Sallberg M. GB virus C/hepatitis G virus. Scand J Infect Dis 2001; 33(8):572-80. https://doi.org/10.1111/j.1365-2613.2000.00166.x

6. George SL, Varmaz D, Stapleton JT. GB virus C replicates in primary $\mathrm{T}$ and $\mathrm{B}$ lymphocytes. J Infect Dis 2006; 193(3):451-4. https://doi.org/10.1086/499435

7. Kumar D, Arora A, Singh NP, Kohli R, Kar P, Das BC. Hepatitis $G$ virus infection in hemodialysis patients from urban Delhi. Ren Fail 2005; 27(1):87-93.PMID: 15717640

8. Ramos Filho R, Carneiro MA, Teles SA, Dias MA, Cardoso $\mathrm{DD}$, Lampe $\mathrm{E}$, et al. GB virus $\mathrm{C} /$ hepatitis $\mathrm{G}$ virus infection in dialysis patients and kidney transplant recipients in Central Brazil. Mem Inst Oswaldo Cruz 2004; 99(6):63943. https://doi.org/10.1590/S0074-02762004000600019

9. Eslamifar A, Hamkar R, Ramezani A, Ahmadi F, Gachkar L, Jalilvand S, et al. Hepatitis $\mathrm{G}$ virus exposure in dialysis patients. Int Urol Nephrol 2007;39(4):1257-63. PMID: 26622993

10. Amini S, Mahmood abadi SA, Lamian S, Joulaie M, Farahani MM. Prevalence of hepatitis G virus (HGV) in high-risk groups and blood donors in Tehran, Iran. Iran $\mathbf{J}$ Public Health 2005; 34: 41-6.

11. Ghanbari R, Ravanshad M, Hosseini SY, Yaghobi R, Shahzamani K. Genotyping and infection rate of GBV-C among Iranian HCV-infected patients. Hepat Mon 2010; 10: 80-7. PMID: 22312378

12. Zali MR, Mayumi M, Haoufi MM, Nowroozi A. GBV-C infection among patients with hepatitis $\mathrm{C}$ virus in the Islamic Republic of Iran: a preliminary report. EMHJ 1999; 5: 1030-4. PMID: 10983544

13. Yang J, Dai C, Chuang W, Lin W, Lin Z, Chen S, et al. Prevalence and clinical significance of HGV/GBV-C infection in patients with chronic hepatitis B or C. Jpn J Infect Dis 2006; 59: 25-30. PMID: 16495630

14. Tanaka E, Tacke M, Kobayashi M, Nakatsuji Y, Kiyosawa K, Schmolke S, Engel AM, Hess G, Alter HJ. Past and present hepatitis $\mathrm{G}$ virus infections in areas where hepatitis $\mathrm{C}$ is highly endemic and those where it is not endemic. $\mathrm{J}$ Clin Microbiol 1998; 36: 110-114. PMID: 9431931

15. Barusruk S, Urwijitaroon Y. High prevalence of HGV coinfection with $\mathrm{HBV}$ or $\mathrm{HCV}$ among northeastern Thai blood donors. Southeast Asian J Trop Med Public Health 2006; 37: 289-293.

https://doi.org/10.1186/1743-422X-8-345

16. Alvarado-Mora MV, Botelho L, Nishiya A, Neto RA, Gomes- Gouvêa MS, Gutierrez MF, Carrilho FJ, Pinho JR. Frequency and genotypic distribution of $\mathrm{GB}$ virus $\mathrm{C}$ (GBV-C) among Colombian population with Hepatitis B (HBV) or Hepatitis C (HCV) infection. Virol J 2011; 8: 345. https://doi.org/10.1186/1743-422X-8-345

17. Alvarado-Mora MV, Botelho L, Nishiya A, Neto RA, Gomes- Gouvea MS, Gutierrez MF et al. Frequency and genotypic distribution of $\mathrm{GB}$ virus $\mathrm{C}(\mathrm{GBV}-\mathrm{C})$ among Colombian population with hepatitis $\mathrm{B}(\mathrm{HBV})$ or hepatitis $\mathrm{C}$ (HCV) infection. Virol J 2011; 8: 1-7. https://doi.org/10.1186/1743-422X-8-345

18. Dadmanesh Maryam, Mohammad Hosseinzadeh, Hossein Keyvani, et al. Evaluation of Prevalence and Risk Factors of Hepatitis G Virus Infection Among Hemodialysis Patients Referred to Iranian Army Hospitals in Tehran During 2012-2013 2015; 15(1): e18322. https://doi.org/10.5812/hepatmon.18322 
19. Singh, Shivank; Blackard, Jason T. "Human pegivirus $(\mathrm{HPgV})$ infection in sub-Saharan Africa-A call for a renewed research agenda. Reviews in Medical Virology 2017; 27 (6): e1951. https://doi.org/10.1002/rmv.1951

20. Stapleton JT, Foung S, Muerhoff AS, Bukh J, Simmonds $P$. The GB viruses: a review and proposed classification of GBV-A, GBV-C (HGV), and GBV-D in genus Pegivirus within the family Flaviviridae. The $\mathrm{J}$ General Virol 2011; 92 (Pt 2): 233-46. https://doi.org/10.1099/vir.0.027490-0

21. Feng Y, Zhao W, Feng Y, Dai J, Li Z, Zhang X, et al. A Novel Genotype of GB Virus C: Its Identification and Predominance among Injecting Drug Users in Yunnan, China. PLoS ONE 6 (10): e21151.

https://doi.org/10.1371/journal.pone.0021151

22. Davod Javanmard, Makvandi Manoochehr, Hajiani Eskandar, Khalafkhany Davod, Samarbaf Zadeh ALI REZA. Hepatitis $G$ virus and its prevalence and genotypes in patients with hepatitis B and C in Ahvaz, southwestern Iran. Turk J Med Sci 2013; 43:1203-55.

https://doi.org/10.3906/sag-1203-55
23. Ross RS, Viazov S, Schmitt U, Schmolke S, Tacke M, Ofenloch- Haehnle B, et al. Distinct prevalence of antibodies to the E2 protein of GB virus C/hepatitis G virus in different parts of the world. J Med Virol 1998; 54 : 103-106. https://doi.org/10.1016/S0928-8244(02)00399-1

24. Hinrichsen H, Leimenstoll G, Stegen G, Schrader H, Fölsch UR, Schmidt WE. Prevalence of and risk factors for hepatitis $\mathrm{G}(\mathrm{HGV})$ infection in haemodialysis patients: a multicentre study. Nephrol Dial Transplant 2002; 17: 271-275. https://doi.org/10.1093/ndt/17.2.271

25. Fogeda M, Navas S, et al. In vitro infection of human peripheral blood mononuclear cells by GB virus C/hepatitis G virus. J Virol 1999; 73: 4052-4061. PMID: 10196301

26. Barbosa Ade J, Baggio-Zappia GL, Dobo C, Alves-Sousa VK, Lanzara Gde A, Silva ID et al. CF. Analysis of GB virus $\mathrm{C}$ infection among $\mathrm{HIV}-\mathrm{HCV}$ co-infected patients. Rev Soc Bras Med Trop 2009; 42: 591-593. https://doi.org/10.5812/hepatmon.14169 